\section{IJ§ER}

ISSN: 2149-5939
International Journal of Social Sciences and Education Research

Online, http://dergipark.gov.tr/ijsser

Volume: $2(2), 2016$

\title{
An investigation into the discipline approaches of school administrators ${ }^{1}$
}

\author{
Serkan Kadıŏlu ${ }^{2} \quad$ Hatice Kadığlu Ateş ${ }^{3} \quad$ Güler Kanbay $\mathrm{Ak}^{4}$
}

Received Date: $19 / 11 / 2015$

Accepted Date: $11 / 02 / 2016$

\begin{abstract}
The aim of this study is to investigate the discipline approaches of school managers. The study employed qualitative research methods and techniques. The sample of the study consists of the school managers employed in the secondary schools in the district of Başakşehir, Istanbul, in the 2014-2015 educational year. The study unveiled the opinions of 56 school managers on the definition and aims of the concept of discipline, and, at the same time, revealed their discipline approaches that they have adopted. Data were collected from school managers through a semi-structured interview. Interviews were videotaped. The study took approximately two months. According to the findings, school managers defined discipline as a way of yielding desired behaviors, of complying with rules and regulations, rewarding and motivating the employees, and maintaining order in the institution. However, it was also found that some school managers defined discipline as a punishment for undesired behaviors. It was found that school managers think that discipline aims to secure productive functioning of the institutions, to get things done neatly, to help the personnel to be successful, to prevent all possible problems, to make the personnel abide by the rules and regulations and to organize the things to be done. The study also found that among the attitudes that the school managers take on when they implement discipline are encouragement and rewarding instead of prohibition, and identifying the reasons for, and preventing, indiscipline. Based on these findings, it was concluded that the majority of school administrators have preventive approaches towards indiscipline. Some school managers have such attitudes as forcing the employees to act properly, developing an attitude towards the undisciplined personnel, and threatening which shows that they have corrective approach towards indiscipline. School managers that punish the undisciplined personnel in line with the requirements of laws and regulations by giving justifications have the punitive-prohibitive discipline approach which is based on punishment and prohibitions. A small amount of school managers that participated in the study was found to have a revenge-based discipline approach towards the undisciplined employees. It was concluded that managers in this group develop such approaches as waiting for the undisciplined behaviors that require heavy punishment; not helping the personnel in their difficult times, and depriving them of their rights. Based on the findings, it can be said that school managers are knowledgeable with the definition and aims of discipline; that they usually have the preventive approaches towards indiscipline; and that there are very few school managers that have revenge-based approaches towards indiscipline.
\end{abstract}

Keywords: Discipline approaches, School manager, Educational management, Secondary school

\section{Introduction}

Creating and implementing discipline in the school is one of the most important problems on which the educationalists ponder. It can be said that the concept of discipline has two dimensions. On one side are the predetermined rules to abide by and on the other side are the criteria that show the ways of implementation, and the level, intensity and the results of these rules. Discipline

\footnotetext{
${ }^{1}$ This paper was presented orally at the International Conference on Social Sciences and Education Research held in Antalya on 29-31 October 2015.

2 Institute of Social Sciences, Istanbul Sabahattin Zaim University serkan1955@hotmail.com

3 hatice.kadiogluates@izu.edu.tr Department of Gifted and Talented Teaching, Department of Special Teaching, Faculty of Education, Istanbul Sabahattin Zaim University

${ }^{4}$ 50. Y11 İlkokulu, lovable-mad@hotmail.com
} 
Kadıŏglu, S., Kadıŏlu Ateş, H., Kanbay Ak, G. (2016). An investigation into the discipline approaches of school administrators. International Journal of Social Sciences and Education Research, 2 (2), 567-582.

should not be seen merely as a set of ordinary rules to abide by. The notion of discipline is usually articulated as synonymous to punishment as a result of undesirable behaviours (Sarıtaş, 2005).

An important principle is that human beings are responsible for meeting their own needs and that others' socially unacceptable behaviours should not hinder this. The second principle is like this: Undisciplined behaviors can be considered as honest attempts that may have been planned in order to hurt others or to stand in others' way. Even these behaviors may have been displayed in order to meet the supressed needs of the person displaying such behaviors, and to avoid his own failures and rejections.

A strong support for the responsible behaviors of children, executives and parents must be an inseparable part in the establishment of correct systems of discipline and "beyond discipline" systems (Celep, 2004). As in all other things, the sense of discipline is in a fast change and progress. Within the scope of this change and progress, the characteristics of the old and new (modern) sense of discipline can be listed as follows (Ilgar, 2005).

1. Old sense of discipline: In the old sense of discipline, the interests, wants and expectations of a student are supressed. The teacher is strict and obeying the rules is mandatory. The student is encouraged to be silent and passive. Any unwanted behavior of the student is punished. The student is threatened with low marks and violence.

2. New (modern) sense of discipline: In this sense of discipline, a student's interests, wants and expectations are important and they are guided. Discipinary rules are more flexible and rational. The silent presence of a student in the classroom is seen as the presence of a problem. This sense of discipline emphasizes "dos" rather than "don'ts" Students' active presence in the classroom and rewarding their positive behaviors are essential. Punishment is rarely resorted to. The principles of equality and justice are followed in practice. This sense of discipline aims to develop an individual's sense of democracy. Generations are educated and prepared for the future in schools. Education in schools are carried out in a planned way. Desired behaviors are created in students in schools by doing educational activities that are pre-planned according to the needs of the individuals and society. The knowledge, skills and behaviors to be acquired by students in schools are predetermined (Akar, 2002).

The concept of management has been in a process of development for centuries. The concept of management means the most suitable management of the assests of the profit-making companies according to the goals of the companies. This concept is rather new and this is because there were not any big production-based companies until the industrial revolution in the $18^{\text {th }}$ century. In this sense, the long period before the industrial revolution can be named as 'the period before the concept of management' or 'the period before scientific management'. If we consider the order takers and order givers during the period between the first human society and the $18^{\text {th }}$ century, we see that the concept of management goes as back as to the primeval days (Ertürk, 2001). Although management is a process, it is an organizational activity which is essential for the achievement of the organizations. It is impossible to think of organizations without management. The management mentality of organizations reflects the identity of the organization as well as the level of achievement (Güney 2012).

Management is a universal process and it studies human relations and behaviors. That individuals can coexist with other individuals in human relations is the proof of the view that any human being is a manager. Mastery means steering and controlling the organizations that help 
Kadıoğlu, S., Kadıoğlu Ateş, H., Kanbay Ak, G. (2016). An investigation into the discipline approaches of school administrators. International Journal of Social Sciences and Education Research, 2 (2), 567-582.

plan the time and activities of human beings. In this way, human beings can manage themselves. If we look at it at a higher level, a chief physician keeps his hospital going, a farmer his farm, a managing director his company, and a dean his faculty. Although these examples seem quite different from each other, indeed the common aim of each of them is management (Güney, 2007).

In modern day information societies, organizations have increased their human and economic resources for globalization, which has made things more complex and risky. As a result of these developments, a class of executives has started to come into existence. And the developments in this area have been called 'management revolution' in the management literature (Dinçer and Fidan, 2009). With the management revolution, things are done more quickly and more smoothly.

As can be seen from these definitions, management has become a social fact as well as a group activity. Therefore, it applies to all kinds of groups and organizations. In other words, management is a function of all organizations from the smallest (family) to the largest (the state).

A manager is one who makes plans according to the vision developed by the leader and who accomplishes the aims of the company by suitably implementing these plans. If you ask a midlevel or a top executive what he does, he will most probably say that he plans, organizes, coordinates and inspects. However, if you observe these people, you will have difficulty in associating what they say with what they do and the way they use their time (Baltaş, 2000).

Although the concepts of leader and leadership have always attracted attention in management literature, there is no agreed-on definition of it. Basically, the term leadership is considered to be a concept which is rich and multifaceted with different meanings. However, there is a consensus on the fact that the term leadership encapsulates the interactive process between the leader and his followers in line with the achievement of the goals of the organization (İbicioğlu, Çiftçi and Kanten, 2010).

The concept of leadership is prospective. Leaders are responsible for the survival of the organization, finding out the ways things are done and what are important in the organization, creating a vision, and making the personnel of the organization adopt this vision (Baltaş, 2002).

Different from management, leadership has a characteristic that requires involvement. In the complex structure of the market in business life, both management and leadership characteristics are necessary. While leadership deals with such issues as change and supervision of the change, management concentrates on such issues as stabilization, protection of the business enterprise and maintenance of the enterprise in such basic areas as maintenance of quality and profitability (Baltaş, 2003).

Table 1. Key differences between a leader and a manager

\begin{tabular}{|l|l|}
\hline \multicolumn{1}{|c|}{ Manager } & \multicolumn{1}{c|}{ Leader } \\
\hline is a manager & is innovative \\
\hline is repetitive & is original \\
\hline is progressive & relies on truth \\
\hline has short-term views & has long-term views \\
\hline asks 'how' and 'when' & asks 'why' \\
\hline looks towards the ground & looks horizontally \\
\hline is classically a good soldier & is himself/herself \\
\hline his thoughts are correct & has correct thoughts \\
\hline accepts the existing state & challenges the existing state \\
\hline
\end{tabular}


Kadıŏglu, S., Kadıŏlu Ateş, H., Kanbay Ak, G. (2016). An investigation into the discipline approaches of school administrators. International Journal of Social Sciences and Education Research, 2 (2), 567-582.

The differences between a leader and a manager can be summarized as follows: A leader focuses on change, guides the people in the organization, has a certain vision, establishes his authority through motivation, instills a sense of contention into people around him, has the power to realize the common aim, motivates the people in the organization, is their source of inspiration, and enlightens the people around him with his profound knowledge and experience. A manager focuses on the protection of the existing state of the organization. He has short-term views for the organization. He draws his authority from the bureaucratic structure. He relies on supervision; has the power that is based on award and punishment; is a supervisor, organizer and coordinator (Yeşilyurt, 2007).

\section{The concept of discipline}

The word discipline comes from Latin 'disciplina' or French 'discipline'. Literally, it means the whole of the rules, regulations and laws that govern a society (Sönmez, 2006). Discipline lessens the disorder of the organizational life and forces the people in the organization to abide by the contract between themselves and the organization. In the Turkic states, the concept of discipline has been perceived as "to secure law and order". However, Ottomans used the word more as a military term. In this sense, discipline can be defined as bringing the soldiers under control, making them commit themselves to their work, and establishing moral bonds among people. However, in all these definitions, while the meanings of strict training and voluntary training come to the fore, punishment and negative meanings do not (Atay, 2013).

Discipline is the body of such implementations as keeping the personnel under control through motivation and awards, making them obey the rules and orders, fixing the behaviors, using punishment or a sanction in order to prevent a deviant behavior from happening (Ergin 2006).

\subsection{Discipline approaches}

\subsubsection{Punitive and prohibitive discipline approach}

This approach was widely used between the $15^{\text {th }}$ and $17^{\text {th }}$ centuries. Divinity was replaced by the sense of social justice. Those who broke the rules and laws were exposed to harsh physical punishment. Those who broke the rules were exposed to such sanctions as capital punishment, torture and exile. In this approach, the rules, regulations and prohibitions that students must obey and the punishments are predetermined (Sayın, 2001).

According to Sarıtaş (2000), although punitive discipline approach is not considered a suitable discipline approach in a school, when some of its aspects are used with other discipline approaches they may serve to attain the desired behavioral changes. The most important disadvantage of the punitive approach is that although it stops the unwanted behavior, it does not teach the desired behavior to individuals. It is believed that infrequent, appropriate, timely and fair punishment will reduce the negative functions of the punishment and will increase its benefits. He emphasizes that during the implementation of punishment, it is possible that one may involuntarily generate negative behaviors in individuals. Punishment must be considered when all positive precautions do not yield any benefits or create enough effect. It may not always be possible for everyone to obey the predetermined rules. In such a case, because breaking the rules will affect the educational activities of other students negatively, such behaviors require punishment (Sarıtaş, 2000). 
Kadıoğlu, S., Kadıŏlu Ateş, H., Kanbay Ak, G. (2016). An investigation into the discipline approaches of school administrators. International Journal of Social Sciences and Education Research, 2 (2), 567-582.

\subsubsection{Revenge-based discipline approach}

This discipline approach was common until the $15^{\text {th }}$ century and was mainly based on the sense of religion of the clergy. Based on their divine characteristic and the authority that they have, they can avenge upon a convict in the way they like without taking any responsibility. Revenge-based discipline approach does not take into consideration the causes and solutions of disruptive and negative behaviors that are difficult to correct. This approach prefers the easy way out. This is a method of putting the doer of the unwanted behavior in a difficult position in one of his weak moments and of depriving him of his rights (Bican, 1994). The reflection of this approach in education is that some teachers make some discipline problems their personal problems and therefore they treat students pitilessly.

\subsubsection{Corrective discipline approach}

The aim of corrective discipline is to correct the unwanted behaviors of the personnel and others through punishment and to threaten them not to repeat the same unwanted behaviors in the future. Corrective discipline warns the personnel to act in line with the predetermined rules and regulations by threatening or forcing them to do so. Corrective discipline approach tries to make an individual develop dispositions, wishes and behaviors that aim to protect the social order instead of dispositions, wishes and behaviors that aim to break the social order (Gökhan, 2007).

A student may display unwanted behaviors for a variety of reasons. The aim here should be to find the exact causes of the unwanted behaviors, to eradicate the main factors that lead the student to display such behaviours, and to help student get rid of the problem. This approach aims to make sure that the student will not commit such crimes again by assuming a particular attitude towards the student if he commits crimes again despite all preventive precautions (Sarıtaş, 2000).

The important thing here is the desire and determinaion of adopting, thinking about and trying to understand the problem, and making all these as a team work as far as possible.

\subsubsection{Preventive discipline approach}

The basis of this approach is its view of optimism for the human nature. According to the view that this approach advocates, human beings do not have an innate evil nature and innate tendency to do evil things, but they learn evil things, laziness and egoism later in life from their environment (Hesapçığlu, 1998).

Environmental factors are important in the life of a child. For when a child comes to school, he brings with him the effects of his environment on him. According to this approach, if the environmental factors that affect the child's behaviors negativey can be controlled, it will be possible for the child to develop appropriate behavioral habits. This approach aims to produce human beings who are aware of their responsibilities and who can use the democratic methods efficiently. This can be achieved through a separate educational program which will be based on orders and experiences of others in order to get the inner reactions under control. This method involves dealing with the problem before it appears, predetermining and removing the contexts which will cause the problem (unwanted behaviours) to appear, and taking the necessary precautions (Bican, 1994).

Sarıtaş (2000) summarizes the general characteristics of the preventive discipline approach as follows: 
Kadıŏlu, S., Kadığlu Ateş, H., Kanbay Ak, G. (2016). An investigation into the discipline approaches of school administrators. International Journal of Social Sciences and Education Research, 2 (2), 567-582.

- The purpose of discipline is not to threaten, intimidate or punish but to correct, win trust, help, and support.

- The character and personality of each student is taken into consideration.

- It is based more on encouragement than on prohibition.

- It places importance on student participation.

- It is objective, impartial and fair.

- It is primarily interested in the change in students.

- There is a social awareness in classroom activities.

\subsection{Discipline in education}

Discipline in education means much more than a list of rules to be obeyed. The definition of discipline in education is: to teach the student the desirable behaviors, to monitor whether or not the student adopt those behaviors, to reward the student if he adopts those behaviours better than expected, and to punish the student if he adopts those behaviors worse than expected. In this sense, discipline is to teach the desirable behaviors to an individual and to make him aware of them. Such a sense of discipline means the same as education (Başaran, 1996).

Discipline in education means that a student has had the awareness and habit of evaluating and controlling his behaviors according to both himself and other students. It also means that a student is temperate and respectful in their relationships with others, that his behaviors and his inner world are coherent, and that he has both moral and character maturity.

In this sense, discipline is considered to be moral and character education rather than discipline (Ökdem, 2002). The concept of discipline is sometimes used to mean the same as punishment after an unwanted behavior. In fact, discipline does not mean only punishing the students. Punishment is only one function of discipline (Sarıtaş, 2000). Punishment is a reaction to a destructive behavior. On the other hand, discipline is resorted to in order to prevent the desructive behavior and the resulting reaction (Küçükahmet, 2004).

Discipline is a must in educational institutions in order to get rid of negative behaviors and to raise healthy generations. A student who does not have an inner mechanism to control himself may be of the opinion that there is nothing to limit himself. And this is the most important factor which creates disorder (Uzun, 2001). If students internalize the right values and if they act under the influence of these values, they will become responsible individuals in society, school and classroom (Nelson, 2002).

\subsection{Discipline practices in schools}

A school is a social system and has its peculiar aims. The effectiveness and productivity of a school are closely related with the degree to which it achieves its goals. For this reason, it is necessary for the school to have an organizational normative order with some rules and principles in order not to deviate from its aims (Sarıtaş, 2000).

A school is also a self-test place created by the society. According to Tezcan (2003), a school is a place where one can directly witness the effects of the society and adults on a child. Educational institutions must make the students adopt the agreed-upon values, norms and attitudes of a society in a planned and controlled way and observe whether the students act in line 
Kadıoğlu, S., Kadığlu Ateş, H., Kanbay Ak, G. (2016). An investigation into the discipline approaches of school administrators. International Journal of Social Sciences and Education Research, 2 (2), 567-582.

them. In this sense, it can be said that educational institutions have the function of an important social control tool (Güçlü 2004).

\subsubsection{Components of discipline in a school}

There are some discipline-related problems inside and outside the school. These problems stem from students or administrators or teachers.

The basic process in education is to make students adopt the desirable behaviors. Each student is different and unique in terms of hereditary, physical, cognitive and emotional characteristics. A student's behavioral habits, intelligence and skills, and the differences in his past experiences are all reflected in his behaviors (Başar, 2004).

Another family-based cause of undisciplined behaviors of students in schools and classrooms is the attitudes of parents. The negative attitudes and behaviors of parents who have not proved themselves and who have not had a positive personality are directly reflected in the behaviors of the child and consequently the child exhibits similar reactions to his teachers and peers (Yüksel \& Ergün, 2005).

According to Doyle (1986), especially the dull learning activities and trivial and detailed load of information in the lessons have an effect on the occurrence of the unwanted behaviors in the classroom. The use of the same teaching method in all classes creates monotony and bores the students (Akar, 2002). A student who gets bored in the classroom and who does not like the teaching materials offered will naturally resort to different ectivities that will entertain himself. For example, he speaks to his friends, looks outside, etc. For this reason, teachers should make the learning activities more interesting for students and make them participate in the lesson more actively. Students usually get bored in the lessons which do not serve their needs and aims, which they have difficulty in understanding, and which they fail. Likewise, learning environments where students are passive and where teaching is teacher-centered may make the students bored. A student who is always a listener may be distracted after a while and therefore unwanted behaviors may occur. As the intensity of concentration and the amount of time span that a student spend for learning increase, there will be a decrease in the occurrence of unwanted behaviors.

Some of the disciplinary problems stem from teachers' lack of personal skills or from their insufficient training. In schools, most of the time should be spent in teaching-learning activities; however, in many schools, teachers who are not trained in problem solving spend most of their time by trying to solve students' problems or they are striving with the problems created by hyperactive and rebellious students that the teachers can not control (Kök, 2007). If the learning process is not enjoyable, students may show such behaviors as resistance, low motivation, lower attention span, indifference, anger, and a desire to get rid of the system as soon as possible. Increasing problems make teachers angry and then they may tend to use the power arising from their authority; The teaching process becomes a boring and unpleasant process (Akçadağ, 2005).

\subsubsection{A manager's role in implementing discipline in a school}

The school principal takes on an important leadership role in enforcing discipline in a school by displaying an effective management and exemplary character. As the educational leaders, the school principals must ensure the effectiveness of disciplinary implementations and strengthen the education. In general, the principals of disciplined students are the role models who are seen everywhere in a school. According to Duke (1999), principals must not manage the school by sitting in their seats but by walking around the school; they must be busy with greeting the 
Kadıŏlu, S., Kadığlu Ateş, H., Kanbay Ak, G. (2016). An investigation into the discipline approaches of school administrators. International Journal of Social Sciences and Education Research, 2 (2), 567-582.

students and personnel, and must keep an eye on the problematic areas in the school. The principal must enforce and maintain the discipline by exercising an effective management and displaying a model personality. Nelson's (2002) remark is also similar to that of Duke's that a principal must not manage the school by sitting in his room but by walking around the school; he must be busy with greeting the students and personnel, and must keep an eye on the problematic areas in the school.

The success of a manager depends on his success in coping with the discipline problems. Inadequate education stems from the lack of a suitable discipline system. According to Cemaloğlu (2007), depending on the management practices the management of a school can create an effective discipline environment as well as an ineffectice, unsuccessful and problematic school environment.

A school can be defined as an organizational structure which consists of efforts and mutual interactions of individuals that come together in order to realize their common aims. That the school administration uses all the available resources in the best way possible is of utmost importance in achieving the aims of the organization. One of the most important elements of a succssful discipline plan is that all the personnel of a school feel themselves responsible for creating and maintaining desired student behaviors as the first condition of education (Nelson, 2002).

School administrators are the key persons in creating the 'good discipline' because they are they are the most important persons in all activities of the school. Compared to schools managed by ineffective and weak school principals, in schools where principals function as educational leaders students are more successful, teachers work more enthusiastically, there are less disciplinary problems, and the quality of the school increases. A good discipline program does not make a weak principal strong, but it makes an effective principal more successful in the management of the school (Myers, 1990).

School administrators and teachers play an important role in creating an effective discipline. The discipline program should encourage school attendance of students, maintain the necessary discipline with maximum effort, deal with students' problems when necessary, solve problems by negotiation instead of adopting a strict administrator-personnel relationship, and in this way the necessary discipline will be created. With clear but not strict attitudes of the admininistration and teachers, students' relationships with the school will be extremely productive. In organizations without discipline, it is not possible to talk about success and productivity. In order to avoid such a situation, all the school personnel are responsible for doing their best in preventing undisciplined behaviors. For this reason, because school administrator are responsible for creating and maintaining a discipline system, finding out about how successful and active they are in this has been considered an important problem of the educational system.

The aim of this study is to find out about the approaches of school administrators to discipline. The main question of the study was chosen as "What are the discipline approaches of school administrators?". In line with this major question, the following minor questions were also investigated:

- According to school managers, what is the definition of discipline?

- What are the attitudes of school managers when implementing discipline? 
Kadıoğlu, S., Kadıoğlu Ateş, H., Kanbay Ak, G. (2016). An investigation into the discipline approaches of school administrators. International Journal of Social Sciences and Education Research, 2 (2), 567-582.

- What kind of disciplinary approaches do school managers have?

This study is important in that it will explore and evaluate the disciplinary approaches of school administrators, which will allow for the necessary recommendations to be made in line with the findings. This study is also important because there have been no studies on the identification of the perceptions of discipline approaches of school administrators in secondary education, although similar studies have been carried out.

\section{Method}

This section presents the population and sample of the study, preparation and administration of the data collection tool, and the analyses of the data collected.

This study employed a qualitative research method and was carried out in the natural environment, which allowed for more explanation and interpretation of what was experienced. Because this study is on effective schools and employed a qualitative research method, the findings cannot be generalized; however, it allows for eliciting in-depth data that will explore the views and their justifications on schools by employing observation and interview tools.

\subsection{Research model}

In line with the research topic, the phenomenological method was chosen and the research model was created accordingly.

The phenomenological approach aims to carry out detailed and in-depth investigations about the phenomena that we may encounter in our daily lives. The phenomena are experienced, explained and interpreted by individuals. It is inevitable that differences emerge in realities due to the differences in the perceptions of individuals. Thus, on the basis of various life experiences, phenomenological research aims to reach the core of the understanding underlying the experience. Phenomenological research is distinct from quantitative research methods in terms of its subjective characteristic. Phenomenological research attaches importance to the experiences of the individuals, and reaches conclusions on the basis of the meanings that individuals assign to their experiences (Akturan \& Esen, 2008).

\subsection{Sample of the study}

The focus of the phenomenological research is the experiences of individuals. For this reason, the sample of the phenomenological research will consist of individuals who experienced the phenomena. Therefore, the study employs the purposive sampling method. Including a lot of people in a study does not insure obtaining more information. The important thing here is to obtain detailed and in-depth information about the experiences of people who are the focus of investigation (Akturan \& Esen, 2008).

In line with what has been said above, the sample of the study consists of the school administrators employed in the secondary schools that were chosen from among 66 public educational institutions in the district of Başakşehir, Istanbul, in the 2014-2015 educational year. 56 administrators working in these schools that volunteered to participate in the study and they were given interview forms. Of the participants, 15 administrators had 7-10 years of length of service and 31 teachers 10-13 yeaars. 10 teachers had 13-16 years of length of service. Of the 56 school administrators, 18 were school principals and 38 were deputy school principals. 
Kadıŏglu, S., Kadıŏlu Ateş, H., Kanbay Ak, G. (2016). An investigation into the discipline approaches of school administrators. International Journal of Social Sciences and Education Research, 2 (2), 567-582.

\subsection{Data collection}

Participants were interviewed with open-ended questions, the aim of which was to elicit the views of school administrators on discipline approaches. All 56 participants responded the interview questions in writing. Collecting the interview forms took approximately 15 days. The interview questions that the school administrators responded are given in Appendix 1. The next step was data analysis.

\subsection{Data analysis}

There are two basic approaches in phenomenological method: Existential phenomenolgy and descriptive phenomenology. Developed by Heidegger, existential phenomenology is an approach that is based on "the nature of being and its relationships". In the descriptive phenomenology developed by Husserl, the aim is to describe the core of the experienced phenomenon (Akturan and Esen, 2008). In data analysis, the present study employed the analysis method of descriptive phenomenology developed by Giorgi. The descriptive analysis process developed by Giorgi has four stages:

1. Reading the entire description in order to get a general sense of the whole,

2. discrimination of participant's expressions into meaning units,

3. Transformations of the meaning units into psychological language,

4. Synthesis of transformed meaning units into a consistent statement of the structure of the experience.

5. Final analysis of all the statements of the participant's experience into one statement of the structure of the experience that describes and captures the essence of the experience (Giorgi and Giorgi, 2008).

Data was analysed in parallel with the phenomenological data analysis method. First, all the descriptions were read once in order to get a general sense of the whole. Second, all the descriptions were read a second time in order to get a sense of the phenomenon under investigation. Third, the responses to the questions were discriminated into separate meaning units and the psycholgical meanings of the statements were determined, and a profile was created for each participant. Finally, the structure of the phenomenon was created by synthesizing these meaningful units and the findings section of the study was shaped according to this structure.

\section{Findings and discussion}

This part of the study presents the findings obtained through the analysis of the responses of the 56 participants working in the secondary schools in the district of Başakşehir, İstanbul. The findings are presented in tables.

\subsection{School managers' definition of discipline}

School managers were asked questions about the definition of discipline and the responses were grouped as in Table 2 . 
Kadıoğlu, S., Kadıŏlu Ateş, H., Kanbay Ak, G. (2016). An investigation into the discipline approaches of school administrators. International Journal of Social Sciences and Education Research, 2 (2), 567-582.

Table 2. School managers' definition of discipline

\begin{tabular}{|l|c|}
\hline \multicolumn{1}{|c|}{ Definitions Stated } & Frequency (f) \\
\hline It is a way of making people adopt the desired behaviors & 32 \\
\hline It is complying with the rules and regulations. & 24 \\
\hline It is rewarding the personnel & 19 \\
\hline It is punihment for unwanted behaviors & 12 \\
\hline It is generating motivation for the personnel & 11 \\
\hline It is the prevention of the institutional disorder & 7 \\
\hline It is combining the goals of individuals and the institution & 4 \\
\hline
\end{tabular}

A total of 109 definitions of discipline were elicited from the respondents. $29.4 \%$ of the respondents $(\mathrm{N}=32)$ defined discipline as a way of making people adopt the desired behaviors. One participant stated: "By means of discipline, both students and teachers adopt the desired behaviors. It is impossible to achieve this without discipline." $22 \%$ of the respondents $(\mathrm{N}=24)$ defined discipline as complying with the rules and regulations. $17,4 \%$ of the respondents $(\mathrm{N}=19)$ defined discipline as rewarding the personnel and $11 \%$ of the respondents $(\mathrm{N}=12)$ defined it as punishment for unwanted behaviors. $10.1 \%$ of the respondents $(\mathrm{N}=11)$ defined discipline as generating motivation for the personnel. While $6,4 \%$ of the respondents $(\mathrm{N}=7)$ defined discipline as prevention of institutional disorder, only $3.7 \%$ of the respondents $(\mathrm{N}=4)$ defined it as the combination of the goals of individuals and the institution.

\subsection{The aim of discipline according to school managers}

Table 3. The aim of discipline according to school managers

\begin{tabular}{|l|c|}
\hline \multicolumn{1}{|c|}{ Views Stated } & Frequency (f) \\
\hline To ensure productive functioning of the institutions & 29 \\
\hline To get things done neatly & 21 \\
\hline To make the personnel successful & 17 \\
\hline To prevent all likely problems & 14 \\
\hline To abide by the laws and regulations & 9 \\
\hline To organize things & 5 \\
\hline
\end{tabular}

A total of 95 views about the aims of discipline were elicited from the 56 respondents in the sample. $30,5 \%$ of the respondents $(\mathrm{N}=29)$ defined the aim of discipline as ensuring productive functioning of the institutions. One of the school managers stated on this issue: "The primary aim of an institutions is to be successful. In order to be successful, the most important condition is to ensure a productive operation of the institution. The aim of discipline is to ensure this productive operation." $22.1 \%$ of the respondents $(\mathrm{N}=21)$ defined the aim of discipline as getting things done neatly. $17,9 \%$ of the respondents $(\mathrm{N}=17)$ defined the aim of discipline as making the personnel successful. $14.7 \%$ of the respondents $(\mathrm{N}=14)$ defined the aim of discipline as preventing all likely problems while $9.5 \%$ of the respondents $(\mathrm{N}=9)$ defined the aim of discipline as abiding by the laws and regulations. Only 5,3\% of the respondents $(\mathrm{N}=5)$ defined the aim of discipline as organizing things.

\subsection{Discipline approaches of school managers}

Some questions in the interview form aimed to elicit the discipline approaches of school managers and the responses are grouped as in Table 4. 
Kadıŏglu, S., Kadıŏlu Ateş, H., Kanbay Ak, G. (2016). An investigation into the discipline approaches of school administrators. International Journal of Social Sciences and Education Research, 2 (2), 567-582.

In terms of approaches to discipline, a total of 84 responses were elicited from the 56 respondents. $20,2 \%$ of the respondents $(\mathrm{N}=17)$ stated that they prefer encouragement and rewarding instead of prohibition. $17,9 \%$ of the respondents $(\mathrm{N}=15)$ stated that they identified the causes of indiscipline and prevented them from happening. One manager stated on the issue: "If an employee exhibit an undisciplined behavior, I first try to find out why he/she behaves in that way. After finding out the causes for this misbehavior, I try to eliminate the causes and prevent the undisciplined behavior from happening." $15.5 \%$ of the respondents $(\mathrm{N}=13)$ stated that while implementing discipline, they force the personnel to behave within the confines of rules and regulations. $13.1 \%$ of the respondents $(\mathrm{N}=11)$ stated that they take on a particular attitude towards the undisciplined personnel and threaten them. $10,7 \%$ of the respondents $(\mathrm{N}=9)$ stated that they punish the undisciplined personnel according to the laws and regulations while $8.3 \%$ of the respondents stated that they punish the undsciplined personnel by stating the legal justifications. Another $8,3 \%$ of the respondents $(\mathrm{N}=7)$ stated that they wait for the occurrence of undisciplined behavior that require severe punishment, and only $6 \%$ of the respondents $(\mathrm{N}=5)$ stated that they do not help the employees in their difficult times and deprive them of their rights.

Table 4. the discipline approaches of school managers

\begin{tabular}{|c|c|c|}
\hline Approaches & Approaches Stated & Frequency (f) \\
\hline \multirow{2}{*}{ Preventive } & Encouragement and rewarding instead of prohibition & 17 \\
\hline & Identifying the causes of, and preventing, indiscipline & 15 \\
\hline \multirow{2}{*}{ Corrective } & Forcing to behave according to the rules & 13 \\
\hline & $\begin{array}{l}\text { Taking on a particular attitude towards the undisciplined } \\
\text { and threatening }\end{array}$ & 11 \\
\hline \multirow{2}{*}{$\begin{array}{l}\text { Punitive and } \\
\text { Prohibitive }\end{array}$} & $\begin{array}{l}\text { Punishing the undisciplined according to the laws and } \\
\text { regulations }\end{array}$ & 9 \\
\hline & Punishment by stating the legal justifications & 7 \\
\hline \multirow{2}{*}{ Revenge-based } & $\begin{array}{l}\text { Waiting for the occurrence of undisciplined behaviors that } \\
\text { require severe punishment }\end{array}$ & 7 \\
\hline & $\begin{array}{l}\text { Not helping the personnel in their difficult times, and } \\
\text { depriving them of their rights }\end{array}$ & 5 \\
\hline
\end{tabular}

When we look at the responses in terms of four discipline approaches, we see that $38,1 \%$ of the respondents $(\mathrm{N}=32)$ prefer preventive discipline approach, 28,6\% of the respondents $(\mathrm{N}=24)$ prefer corrective discipline approach, $19 \%$ of the respondents $(\mathrm{N}=16)$ prefer punitive and prohibitive discipline approach, and $14,3 \%$ of the respondents $(\mathrm{N}=12)$ prefer revenge-based discipline approach.

\section{Conclusions, discussion and recommendations}

This section of the study presents the results and makes some recommendations based on the findings of the study.

\subsection{Conclusions}

This study yielded important and striking conclusions on school managers' views about discipline, definition and aim of discipline, and their approaches towards discipline.

It was found that the school managers define discipline variously as a way of making people adopt the desired behaviors, compliance with the rules and regulations, rewarding and motivating 
Kadıoğlu, S., Kadıoğlu Ateş, H., Kanbay Ak, G. (2016). An investigation into the discipline approaches of school administrators. International Journal of Social Sciences and Education Research, 2 (2), 567-582.

the personnel, and maintaining the order in the institution. However, it was also found that some managers define discipline as a punishment for unwanted behaviors.

In terms of the aims of discipline, it was found found that school managers have such diverse views about the aims of discipline as ensuring the productive functioning of the institution, getting things done neatly, making the personnel successful, prevention of all likely problems, abiding by the rules and regulations, and organizing things.

In terms of the attitudes that school managers take on when implementing discipline, the study found that they prefer encouragement and rewarding instead of prohibition, and identifying the causes of the indiscipline and preventing them from happening. It was concluded from this that the majority of school managers have the preventive discipline approach.

Those school managers who force the personnel to behave within the confines of rules and regulations, and those who take on a particular attitude towards the undisciplined personnel and threaten them have the corrective discipline approach.

Those school managers who punish the personnel according to laws and regulations and those who punish the personnel by stating the legal justifications have the punitive and prohibitive discipline approach.

It was foud that a minor group of school managers have revenge-based discipline approach. Those who have this kind of discipline approach exhibit such attitudes as waiting for the occurrence of undisciplined behaviors that require heavy punishment, not helping them in their difficult times, and depriving them of their rights.

Based on the findings of the study, it can be said that school managers have enough knowledge and experience about the definition and aims of discipline; that school managers usually prefer preventive discipline approach; and that a small number of managers have revenge-based discipline approach.

\subsection{Discussion}

In a previous study, Gündoğdu (2007) concluded that all the participating teachers thought that psychological rewarding and prevention methods were the most effective in enforcing discipline to students. Within this context, the findings of the present study have parallels with Gündoğdu's study. Thus, it can be said that the discipline approaches used in schools are similar.

School managers who want to establish their authority in schools due to the problems that they encounter in different occasions may be negatively affected by these problems and therefore they may resort to such punishment types in order to eliminate the problems. Kuzgun (1997) claims that it is possible to implement discipline without punishment or with a light punishment. Some school managers in the present study stated that they adopted punitive discipline approaches, which is parallel to the findings of Kuzgun's study.

Saban (2002) states that psychological punishment serves to change the mental constructs of students that cause negative behaviors, and therefore students must know the reasons for their punishment. This overlaps with the finding of the present study that some managers punish students by stating the legal justifications for punishment.

Baysal (2001) and Saban (2002) found that in social punishment a student is generally isolated from other students. If a student is exposed to social punishment, other students will get social 
Kadıŏglu, S., Kadıŏlu Ateş, H., Kanbay Ak, G. (2016). An investigation into the discipline approaches of school administrators. International Journal of Social Sciences and Education Research, 2 (2), 567-582.

learning from this punishment and therefore they will not exhibit undisciplined behaviors. Baysal and Saban's finding and the finding of the present study that some school managers have corrective discipline approach are complementary.

\subsection{Recommendations}

In line with the findings of the study, the following recommendations were developed:

\subsubsection{Recommendations for researchers}

The study elicited only the school managers' views about the school managers' discipline approaches. Similar studies can also be carried out with teachers, parents and students.

Only the managers of public schools were interviewed. Different findings can be obtained by interviewing the managers of the private schools. Studies carried out in both public and private schools of primary education must be compared.

\subsubsection{Recommendations for school managers}

School managers can be supported through in-service training on discipline applications, and therefore they can get the expected level of information on the issue.

School managers can have more information on discipline approaches.

School managers can be more knowledgeable about effective reconciliation and negotiation skills.

School managers may exhibit preventive attitudes before they directly exercise their authority for disciplinary punishment.

School managers can do their master's studies and become experts in their fields.

School managers can be the pioneers in transferring the disciplinary rules to school personnel, students, parents, and all members of the society.

\subsubsection{Recommendations for policy makers}

In order for the school managers to be professional managers and to be proficient in disciplinary applications, courses and seminars may be useful.

In order to transfer the positive developments about quality and management in private schools into public schools, necessary arrangements should be made in order to realize and improve the interschool cooperation. If needed, the principals of successful private schools can offer counseling about discipline to their colleagues in public schools.

One reason why school managers cannot put into practice their discipline approaches may be the excessive bureaucratic procedures. School managers' workload can be reduced by employing new personnel for vacant positions and therefore they may spare more time for thinking over discipline.

The centralized system in Turkish educational system and school managers' insufficient power in using authority are two important obstacles in the implementation of discipline in schools. The limited flexibility in schools creates problems for managers in putting into practice their ideas of discipline. By allowing schools for more authority, they can be supported to develop distinctive disciplines. 
Kadıŏlu, S., Kadığlu Ateş, H., Kanbay Ak, G. (2016). An investigation into the discipline approaches of school administrators. International Journal of Social Sciences and Education Research, 2 (2), 567-582.

\section{References}

Akar, I. (2002). Öğrenci Davranışlarını Etkileyen Etmenler. Z. Kaya (Ed.), Sınıf Yönetimi İçinde, Ankara: Pegem Yayınları.

Akçadağ, T. (2005). Sorun Davranışların Yönetimi, Etkili Sinıf Yönetimi, Editör:Hüseyin Kıran, Ankara: Anı Yayınevi

Akturan, U. Ve Esen, A. (2008). Fenomenoloji. Seçkin: Ankara.

Atay, S. (2013). Milli Ĕ̆itim Bakanlığına Bağlı Resmi Ortağretim Kurumlarında Görev Yapan Öğretmen Ve Yöneticiler İle U Okulda Okuyan Öğrenci Ve Velilerinin Disipline İlişkin Algllarl (Sakarya Örneği), Yüksek Lisans Tezi, Okan Üniversitesi.

Baltaş, A. (2000). Ekip Çalışması Ve Liderlik. Remzi Kitabevi İstanbul.

Baltaş, A. (2002). Güçlü Şirketleri Yaratan İş Liderleri. Remzi Kitabevi İstanbul.

Baltaş, A. (2003). Rekabette Fark Yaratan Ekip Çalışması. Remzi Kitabevi İstanbul.

Başar, H. (2003). Sınıf Yönetimi . Ankara: Anı Yayıncılık.

Başaran,İ.E. (1996). Eğitim Yönetimi, Ankara: Yargıcı Matbaası.

Bican S. (1994).(Rehber Öğretmen). Eğitimde Bir Boyut Disiplin, Eğitim Ve Toplum, Ankara. http://EKutuphane.Egitimsen.Org.Tr/Pdf/3196.Pdf.

Celep, C. (2004). "Sinıf Yönetimi Ve Disiplin", Anı Yayınc1l1k, Ankara.

Cemaloğlu, N.,(2007). Disiplin İle İlgili Kavramlar, İlkeler ve Uygulamalar, Milli Eğitim Dergisi.

Dinçer, Ö. ve Fidan Y. (2009). İşletme Yönetimine Giriş (7. Baskı), Alfa Yayınları, İstanbul.

Ergin, D. (2008). Okul Yönetiminde Duygusal Zeka Ve Dönüşümsel Liderliğe İlişkin Öğretmen Alglları (Yayımlanmamış Yüksek Lisans Tezi). Kocaeli Üniversitesi Sosyal Bilimler Enstitüsü Eğitim Bilimleri Bölümü Eğitim Bilimleri Anabilim Dalı Eğitim Yönetimi, Teftişi, Planlaması Ve Ekonomisi Bilim Dalı.

Ertürk, M. (2001). İşletme Biliminin Temel İlkeleri, Beta Yayınları, İstanbul.

Giorgi, A.and Giorgi, B. (2008). Phenomenology. J.A. Smith (Edit.), Qualitative Psychology: A Practical Guide To Research Metod. England.

Gökhan, S. (2007). İlköğretim Okullarında Uygulanan Disiplin Uygulamaları Ve Veli Beklentileri Üzerine Nitel Bir Araştırma, Yüksek Lisans Tezi, İstanbul: Yeditepe Üniversitesi Sosyal Bilimler Enstitüsü.

Güçlü, M. (2004). “Ortaöğretim Kurumlarında Disiplin Cezası Alan Öğrencilerin Sosyo-Ekonomik Yönden Incelenmesi”, (Yüksek Lisans Tezi), Kayseri, Erciyes Üniversitesi Sosyal Bilimler Enstitüsü.

Güney, S. (2007). Yönetim Ve Organizasyon, Nobel Yayınları, Ankara.

Güney, S. (2012). Liderlik, Nobel Yayıncılık, Ankara.

Hesapçıŏglu M. (1998), Öğretim İlke Ve Yöntemleri, İstanbul: Beta Yayıncılık.

Ilgar, L. (2005). “Eğitim Yönetimi, Okul Yönetimi, Sinıf Yönetimi”, Beta Yayıncılık, İstanbul.

İbicioğlu H., Çiftçi M. \& Kanten P. (2010). Akademisyenlerin Akıl Hocalığı Eğilimleri İle Liderlik Tarzları Arasındaki İlişkilerin Belirlenmesine Yönelik Bir Araştırma. Süleyman Demirel Üniversitesi Sosyal Bilimler Enstitüsü Dergisi, 12(6), 53-71.

Kök, M. (2007). Ortaöğretim Kurumlarındaki Öğretmen, Rehber Öğretmen, Yöneticilerin Ortaöğretim Kurumları Ödül Ve Ceza Yönetmeliğindeki Ceza Gerektiren Davranışlar İle Cezalara İlişskin Görüşleri Doktora Tezi, Hacettepe Üniversitesi, Sosyal Bilimler Enstitüsü, Ankara. 
Kadıŏlu, S., Kadığlu Ateş, H., Kanbay Ak, G. (2016). An investigation into the discipline approaches of school administrators. International Journal of Social Sciences and Education Research, 2 (2), 567-582.

Küçükahmet, L. (2004). Öğretimde Planlama Ve Değerlendirme, Ankara: Nobel Yayın Dağıtım.

Myers,K.J. (1990). The Relationship Between Administrator Ideology Of Pupil Control And Discipline Effectiveness. Doctor Of Philosopy, Arizona State University, Arizona.

Nelson M.F. (2002). "A Qualitative Study Of Effective School Discipline Practices: Perceptions Of Administrators, Tenured Teachers And Parents In Twenty Schools”, (Doctor Of Education), East Tennessee State University, East Tennessee.

Ökdem, M. (2002). İlköğretim Okullarında Öğretmenlerin Kural Dışı Davranışları, Doktora Tezi, Ankara: Hacettepe Üniversitesi Sosyal Bilimler Enstitüsü.

Öztürk, B. (2003). Sınıfta Istenmeyen Davranışların Önlenmesi Ve Giderilmesi. İçinde Emin Karip (Editör), Sınıf Yönetimi, Ankara: Pegem Akademi Yayıncılık.

Sarıtaş, M. (2000). Sınıf Yönetimi Ve Disiplinle İlgili Kurallar Geliştirme Ve Uygulama, Sınıf Yönetiminde Yeni Yaklaşımlar, Ankara: Nobel Yayın Dağıtım.

Sarıtaş, M. (2005). Sınıf Yönetimi Ve Disiplin İle İlgili Kurallar Geliştirme. Küçükahmet(Editör). Sınıf Yönetiminde Yeni Yaklaşımlar, 4.Baskı. Ankara. Nobel Yayınları.

Sayın, N. (2001). "Sınıf Öğretmenlerinin Karşılaştıkları İstenmeyen Öğrenci Davranışları Ve Bu Davranışların Nedenlerine İlişkin Görüşleri İle İstenmeyen Davranışları Önleme Yöntemleri”,(Yüksek Lisans Tezi), Anadolu Üniversitesi, Eğitim Bilimleri Enstitüsü, Eskişehir.

Sönmez M. (2006). Disiplin Ve Ceza. Ankara: Emel Matbacılık Sanayi

Tezcan, M. (2003). Gençlik Sosyolojisi, Ankara: Natüral Kitap.

Uzun, S.A. (2001). Özgürleştiren Disiplin, İstanbul: Bilge Yayıncılık.

Yeşilyurt, E. (2007). Akademik Ve Yönetimsel Liderlik, Doğu Anadolu Bölgesi Araştırmaları Dergisi, 5 (3), 76-80.

Yüksel, A. ve Ergün, M.,(2005). Sınıfta İstenmeyen Öğrenci Davranışları Ve Çözüm Yolları. Yaşadıkça Eğitim. 